\title{
Identification of novel bacterial lineages as active members of microbial populations in a freshwater sediment using a rapid RNA extraction procedure and RT-PCR
}

\author{
Ian P. Miskin, ${ }^{1,2}$ Paul Farrimond ${ }^{1}$ and Ian M. Head ${ }^{1,2}$
}

Fossil Fuels and Environmental Geochemistry (Postgraduate Institute) ${ }^{1}$ and Centre for Molecular Ecology2, University of Newcastle, Newcastle upon Tyne NE1 7RU, UK
Author for correspondence: Ian M. Head. Tel: +44 191222 7024. Fax: +44 1912225431. e-mail : i.m.head@ncl.ac.uk

\begin{abstract}
A rapid method for the extraction of RNA from the indigenous bacterial communities in environmental samples was developed. The method was tested using anoxic sediment samples from a productive freshwater lake (Priest Pot, Cumbria, UK). The simple protocol yielded rRNA and mRNA of a purity suitable for amplification by reverse transcriptase PCR (RT-PCR). The integrity of the RT-PCR was demonstrated by amplifying 16S rRNA and MRNA for the mercury resistance regulatory gene merR. The diversity of 165 rRNA sequences recovered from RNA and DNA extracted from anoxic Priest Pot sediments was analysed. The $5^{\prime}$ end of extracted 16S rRNA was amplified by RT-PCR and the 165 rRNA PCR products were cloned and sequenced to identify active constituents of the sediment bacterial community. Corresponding analyses were performed upon DNA templates from the same sediment samples. Partial 16S rRNA sequences were obtained from a total of 147 clones (71 rRNA-derived and 76 rDNA-derived). The clone libraries included sequences related to Pirellula staleyi, an aerobic planktonic member of the Planctomycetales, and the recently described candidate bacterial division OP5. Sequences from these groups were recovered in libraries generated from a DNA template but were also present in RNA-derived libraries. Previous studies of anoxic environments have identified sequences most closely related to Pirellula spp. This study, which utilized RT-PCR of 165 rRNA, has provided the first evidence that Pirellula-like bacteria are active in situ in an anoxic environment. Furthermore, members of the recently described candidate division, OP5, were also identified as active constituents of the bacterial community of anoxic Priest Pot sediments. This not only supports the widespread occurrence of OP5 members in diverse environments but suggests that they are active under anoxic conditions.
\end{abstract}

Keywords: rRNA/mRNA, RT-PCR, novel lineages, freshwater sediment, candidate division OP5

\section{INTRODUCTION}

The extraction and manipulation of nucleic acids from environmental samples is a technique increasingly used in microbial ecology (e.g. Ward et al., 1992). Commonly, DNA preparations from environmental samples provide

Abbreviations: RT-PCR, reverse transcriptase PCR; SSU, small subunit.

The GenBank accession numbers for the partial 16S rRNA sequences reported in this paper are AF093594-AF093603. a template for the amplification of specific gene sequences by PCR. Bacterial community structure can be inferred by phylogenetic analysis of $16 \mathrm{~S}$ rRNA gene sequences recovered using these techniques (e.g. Giovannoni et al., 1990; Fuhrman et al., 1994; Gordon \& Giovannoni, 1996). Furthermore, the occurrence of functional genes has been correlated with particular microbial activities (Fleming et al., 1993). However, the ecological significance of the organism from which these gene sequences are recovered cannot be determined since DNA is known to persist in moribund and dead 
cells and may also be present as extracellular DNA (e.g. Ogram et al., 1987; Coolen \& Overmann, 1998). In contrast, RNA is highly labile and rRNA levels, and therefore ribosome numbers, have been correlated with cellular activity (Rosset et al., 1966; Kramer \& Singleton, 1992, 1993; Lee \& Kemp, 1994). Moreover, studies of cultured bacteria have identified that mRNA is typically short-lived having a half-life of only a few minutes (Darnell et al., 1986). Thus, it has been argued that analysis of sequences derived from RNA rather than DNA templates potentially provide a more representative indication of the active members of the bacterial community (Pichard \& Paul, 1993; Teske et al., 1996). However, RNA is more difficult to isolate than DNA. This difficulty is due primarily to the rapid degradation of RNA species by RNases that are both ubiquitous in the environment and highly stable.

Most protocols for the extraction of RNA from the environment have been applied to water or microbial mat samples. The structure of bacterial communities has been investigated by the direct cloning and sequencing of $16 \mathrm{~S}$ rRNA recovered as cDNA from cyanobacterial mats (Weller \& Ward, 1989) and by high-resolution electrophoresis of low molecular mass RNAs extracted from planktonic microbial communities (Höfle, 1992). In addition, DNA fragments generated by reverse transcriptase PCR (RT-PCR) of rRNA extracted from the water column of a stratified fjord have been analysed by denaturing gradient gel electrophoresis (Teske $e t$ al., 1996). Viral communities within sewage and seawater samples have also been identified and quantified by RT PCR (Tsai et al., 1993). Likewise, gene expression in environmental samples has been detected by analysis of mRNAs using hybridization assays (Pichard \& Paul, 1991; Fleming et al., 1993; Nazaret et al., 1994; Jeffrey et al., 1994).

The analysis of rRNA as a means of inferring the composition of the active bacterial fraction, rather than 'total' bacterial community structure has been proposed for several years (e.g. Weller \& Ward, 1989; Pichard \& Paul, 1993). However, to date difficulties in amplifying extracted indigenous rRNA from sediment and soil samples has precluded their study.

Isolation of indigenous RNA from soil and sediment is more problematic than DNA isolation. In general, enzyme-inhibitory materials present within these environments are co-extracted with the nucleic acids (Tsai \& Olson, 1992; Herrick et al., 1993). Fleming et al. (1993), however, have isolated indigenous mRNA transcripts of a naphthalene dioxygenase gene $(n a h A)$ from contaminated soils at a gas manufacturing site. These were quantified by a ribonuclease protection assay and found to correlate with naphthalene mineralization rates and nahA gene frequency in colony blots of culturable naphthalene degraders. Moran et al. (1993) have also presented a protocol for RNA isolation from a range of soil and sediment environments. Samples obtained were of a purity suitable for hybridization analysis; however, enzymic manipulation was not attempted. More recently, Ogram et al. (1995) have reported the successful isolation and RT-PCR amplification of mRNAs from subsurface sediments. A rapid hydroxyapatite spin column method for recovery of RNA from sediments has also been reported (Purdy et al., 1996) but again, it was not reported if the RNA was suitable for RT-PCR. In addition, a method based on isolation of ribosomes from soil has been developed that gives good yields of RT-PCR-amenable rRNA from soil (Felske et al., 1996). However, the last of these procedures requires use of an ultracentrifuge but potentially allows simultaneous isolation of mRNA which is being actively translated.

To date, methods developed for RNA extraction from soils and sediments have, in general, been lengthy and some require expensive equipment (e.g. an ultracentrifuge). Furthermore, some methods may not allow simultaneous isolation of both rRNA and mRNA, may not permit isolation of RNA of sufficient purity for RT$P C R$ and may require lengthy treatments such as dialysis to purify the RNA. The method presented here allows simple, rapid extraction of rRNA and mRNA from small samples of sediment of a purity suitable for RTPCR.

The analysis of bacterial populations by molecular methods frequently identifies $16 \mathrm{~S}$ rRNA gene sequences that cannot be readily attributed to previously described bacterial divisions (e.g. Hugenholtz et al., 1998b). The significance of these uncultured organisms in situ is probably greater than organisms isolated by traditional culture methods. Some of these "novel' divisions, defined primarily by cloned 16S rRNA genes (Hugenholtz et al., $1998 \mathrm{a}, \mathrm{b})$, contain sequences isolated from diverse environments, implying ecological and hence functional diversity exists among the bacteria that comprise these novel divisions. However, recovery of $16 \mathrm{~S}$ rRNA gene sequences yields little physiological information about uncultured taxa. Indeed, the recovery of $16 \mathrm{~S}$ rRNA gene sequences from extracted DNA does not even assure that the source organism was active in situ (e.g. Coolen \& Overmann, 1998). In contrast, the recovery of rRNA sequences from an RNA template using RT-PCR implies that the source organisms were active at the time of sampling. At the very least this is a better indicator of the presence of active cells than sequence data derived from DNA templates.

\section{METHODS}

Collection of sediment samples. Core samples were taken from the profundal sediments of Priest Pot, Cumbria, UK (Ordnance Survey grid ref. SD 358979) using a modified Jenkin surface mud sampler (Ohnstad \& Jones, 1982). Prior to sampling, the coring device was cleaned with absolute alcohol. Recovery of cores from site to laboratory was completed within $40 \mathrm{~min}$ whereupon sediments were sectioned at $1 \mathrm{~cm}$ intervals. After sectioning, samples were frozen immediately at $-70{ }^{\circ} \mathrm{C}$. $\beta$-Mercaptoethanol was added to frozen samples to a final concentration of $1 \%(\mathrm{v} / \mathrm{v})$ and samples were defrosted at room temperature prior to extraction of nucleic acids.

Preparation of labware. Standard precautions were taken to prevent degradation of RNA by RNases (Blumberg, 1987). All 
glassware was treated with diethyl pyrocarbonate (DEPC) and baked overnight. Solutions incompatible with DEPC treatment (e.g. Tris buffers) were prepared in DEPC-treated water prior to autoclaving.

Nucleic acid extraction. Sediment $\left(1 \mathrm{~cm}^{3}\right)$ was placed in a sterile $15 \mathrm{ml}$ screw-cap PTFE container (Cowie Technology) with $3 \mathrm{~g}$ sterile glass beads $(0 \cdot 17-0 \cdot 18 \mathrm{~mm}$ diameter; $\mathrm{B}$. Braun Biotechnology) and $8 \mathrm{ml}$ extraction buffer $(0 \cdot 12 \mathrm{M}$ sodium phosphate buffer, $5 \mathrm{mg}$ lysozyme $\mathrm{ml}^{-1}$ and $1 \%, \mathrm{v} / \mathrm{v}, \beta$ mercaptoethanol, $\mathrm{pH} 8 \cdot 0)$. Samples were agitated $(2000$ r.p.m., for $20 \mathrm{~s}$ ) using a Mikro-Dismembrator U (B. Braun Biotechnology). Homogenates were transferred to a $13 \mathrm{ml}$ polypropylene screw-cap centrifuge tube (Sarstedt) containing $2 \mathrm{ml} 10 \%(\mathrm{w} / \mathrm{v})$ SDS. The tubes were vortexed and incubated at $80^{\circ} \mathrm{C}$ for $30 \mathrm{~min}$ with vigorous shaking every $10 \mathrm{~min}$. Samples were centrifuged $\left(2800 \mathrm{~g}, 4^{\circ} \mathrm{C}, 15 \mathrm{~min}\right)$ and supernatants were decanted and held on ice. The pellets were reextracted with $10 \mathrm{ml}$ extraction buffer and centrifuged once more. The supernatants were pooled, mixed and the nucleic acids precipitated by the addition of 2 vols polyethylene glycol solution $(30 \%$ PEG6000, $1.6 \mathrm{M} \mathrm{NaCl})$. Following a $2 \mathrm{~h}$ incubation at room temperature and centrifugation $(5000 \mathrm{~g}$, $4{ }^{\circ} \mathrm{C}, 30 \mathrm{~min}$ ), the pellet was resuspended in $1 \mathrm{ml} \mathrm{TE}(10 \mathrm{mM}$ Tris $/ \mathrm{HCl}, 1 \mathrm{mM}$ EDTA, pH 8.0). Humic acids were precipitated from solution by the addition of $400 \mu \mathrm{l} 7.5 \mathrm{M}$ potassium acetate. The nucleic acid preparation was incubated on ice for $5 \mathrm{~min}$ and centrifuged $\left(10000 \mathrm{~g}, 4^{\circ} \mathrm{C}, 5 \mathrm{~min}\right)$ to remove the precipitated humic acids. Nucleic acids were recovered from the supernatant by two rounds of ethanol precipitation and the pellets were resuspended in $50 \mu \mathrm{l}$ TE ( $\mathrm{pH} 8.0)$. For the preparation of RNA, DNA was digested with RNase-free DNase I (Boehringer Mannheim). DNase I (40 units) was added to $20 \mu \mathrm{l}$ nucleic acid preparation and incubated for $1 \mathrm{~h}$ at $37^{\circ} \mathrm{C}$. The DNase was inactivated by incubation at $80^{\circ} \mathrm{C}$ for $10 \mathrm{~min}$. Samples were stored at $-70^{\circ} \mathrm{C}$ until use.

Preparation of control DNA templates. Control DNA templates for $16 \mathrm{~S} r R N A$ and merR gene PCR reactions were prepared using the protocol of Pitcher et al. (1989) from Escherichia coli AB1157 and E. coli AB1157(pACYC184:: Tn501) (Brown et al., 1983), respectively. Strains were maintained on nutrient agar (Difco) which, when appropriate, was supplemented with $27 \mathrm{mg} \mathrm{HgCl}_{2} \mathrm{ml}^{-1}$.

Reverse transcription of RNA. RNA was converted to cDNA using Moloney murine leukaemia virus reverse transcriptase (M-MuLV; Promega), following the manufacturer's instructions. 16S rRNA was reverse-transcribed from the universal oligonucleotide primer 536R (5'-CACGGATCC GTATTACCGCGGCTGCTG-3'; modified from Lane $e t$ al., $1985)$. The underlined region of the primer corresponds to a $B a m \mathrm{HI}$ site. Messenger RNA from the mercury resistance regulatory gene, merR, was reverse-transcribed using the oligonucleotide primer pRE (5'-TYCTCGCARTGGGTGC(A-3').

Amplification of CDNA by RT-PCR. Tenfold serial dilutions of CDNA preparations were prepared $\left(10^{\circ}, 10^{-1}, 10^{-2}\right)$ and samples of each dilution used as template for PCR amplification. The cDNAs were amplified using the oligonucleotide primers $8 \mathrm{~F}$ (5'-GTGCTGCAGAGAGTTTGATCCTGGCTCAG-3') (modified from Edwards et al., 1988) and 536R (5'-CACGGATCCGTATTACCGCGGCTGCTG-3'). These amplify the $5^{\prime}$ end $(\sim 530 \mathrm{bp})$ of bacterial $16 \mathrm{~S}$ rRNA. The forward and reverse $16 \mathrm{~S}$ primers incorporated a Pst I and Bam HI site, respectively. Primers pRE $\left(5^{\prime}\right.$-TYCTCGCARTGGGTGCCA-3') and pRMF (5'-ARAAYCTGACCATTGGCGTT-3') were used to amplify a 234 bp fragment of merR from mercury resistance determinants from Gram-negative bacteria.

Template DNA was added to a standard PCR reaction mix to give a total volume of $45 \mu \mathrm{l}$ containing $20 \mathrm{pmol}$ each primer, $10 \mathrm{nmol}$ each dNTP (Pharmacia) and PCR buffer supplied with the DNA polymerase. Reaction mixes were overlaid with $50 \mu \mathrm{l}$ mineral oil (Sigma) in thin-walled microcentrifuge tubes (0.5 ml capacity). A 'hot start' PCR was used (Mullis, 1991). Reaction mixtures were heated to $95^{\circ} \mathrm{C}$ for $4 \mathrm{~min}$ and cooled to $80^{\circ} \mathrm{C}$ before the addition of $5 \mu \mathrm{l} 1 \times$ PCR buffer containing 0.5 units Dynazyme DNA polymerase (Flowgen). PCR was done using a Hybaid Omnigene thermal cycler with the following cycling parameters. For ribosomal cDNAs, 28 cycles of $1 \mathrm{~min}$ at $95^{\circ} \mathrm{C}, 1 \mathrm{~min}$ at $55^{\circ} \mathrm{C}$ and $1 \mathrm{~min}$ at $72^{\circ} \mathrm{C}$, with a final extension step at $72^{\circ} \mathrm{C}$ for $8 \mathrm{~min}$. For merR cDNA, similar cycling parameters were used except $35 \mathrm{cycles}$ and an annealing temperature of $56^{\circ} \mathrm{C}$ were employed. Contamination of RNA templates by DNA was detected by the inclusion of control PCR reactions containing RNA preparations that were not reverse-transcribed.

Corresponding amplification of $16 \mathrm{~S}$ rRNA gene fragments from a DNA template using the same primers was also performed on aliquots of nucleic acid sample that had not been DNase-treated.

Agarose gel electrophoresis. PCR reaction products were analysed by agarose gel electrophoresis $[0.8 \%$ agarose in $1 \times$ TAE [ $40 \mathrm{mM}$ Tris/acetate, $2 \mathrm{mM}$ EDTA, $\mathrm{pH} 7.6$ ) containing $0.2 \mathrm{mg}$ ethidium bromide $\mathrm{ml}^{-1}$ ] at a constant $100 \mathrm{~V}$. Nucleic acids were visualized by UV transillumination.

Cloning and sequencing of PCR products. Amplification products were purified using a QIASPIN kit (Qiagen) following the manufacturer's protocol. PCR products and pUC19 DNA were then cut using Bam $\mathrm{HI}$ and Pst $\mathrm{l}$ (Promega). Digested vector and PCR products were once again purified using a QIASPIN kit. Products and vectors were mixed in appropriate molar ratios and ligated using T4 DNA ligase (Boehringer Mannheim).

Epicurian Coli SURE2 supercompetent cells (Stratagene) were transformed with ligated DNA. Cells $(20 \mu \mathrm{l})$ were pipetted into a cold $1.5 \mathrm{ml}$ microcentrifuge tube and $1 \mu \mathrm{l}$ ligation reaction was added to the cells. The cells were mixed gently by tapping. The tube was then incubated on ice for $30 \mathrm{~min}$. The cells were heat-shocked for $40 \mathrm{~s}$ in a water bath at $42^{\circ} \mathrm{C}$ before incubation on ice for $2 \mathrm{~min}$. LB Broth $(80 \mu \mathrm{l})$, containing $\mathrm{MgCl}_{2}$ and $\mathrm{MgSO}_{4}$ each at a final concentration of $25 \mathrm{mM}$ and glucose at a final concentration of $20 \mathrm{mM}$, was added to the tube. The tube was incubated, with occasional mixing, at $37^{\circ} \mathrm{C}$ for $1 \mathrm{~h}$. Replicate $50 \mu \mathrm{l}$ aliquots were plated onto LB

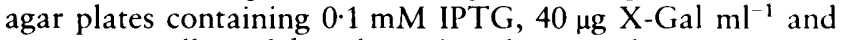
$50 \mu \mathrm{g}$ ampicillin $\mathrm{ml}^{-1}$ and incubated overnight at $37^{\circ} \mathrm{C}$. A transformation control using undigested plasmid was performed. Transformants that contained an insert were identified by blue/white screening and white colonies were plated onto fresh LB agar containing ampicillin and screened for the presence of insert DNA by PCR.

Clone libraries were screened by PCR using forward and reverse pUC/M13 sequencing primers to amplify insert DNA. Thermal cycling parameters used were similar to those outlined above with an annealing temperature of $56^{\circ} \mathrm{C}$. PCRamplified insert DNA of the appropriate size was sequenced using primers $8 \mathrm{~F}$ and $536 \mathrm{R}$ using an $\mathrm{ABI} 373 \mathrm{~A}$ DNA sequencer (Applied Biosystems).

Phylogenetic analysis of rRNA sequences. Sequences were aligned manually with representative $16 \mathrm{~S}$ rRNA sequences from the National Science Foundation Ribosomal Database 
Project (RDP; Maidak et al., 1997). Only unambiguously aligned base positions were used in the analysis. Distance analyses using Jukes \& Cantor (1969) correction and bootstrap resampling were done using the TREECON package (Van de Peer \& de Wachter, 1994) and trees were generated from distance matrices using the neighbour-joining method (Saitou \& Nei, 1987). Parsimony analysis was done using the DNAPAR program from the PHYLIP package (Felsenstein, 1989). Data analysis and manipulation were performed using Genetic Data Environment (Smith et al., 1994) software running on a SPARC 10 workstation (Sun Microsystems).

\section{RESULTS AND DISCUSSION}

\section{RNA extraction and amplification}

The RNA extraction protocol described here was applied successfully for the isolation of RNA from lacustrine surface and subsurface profundal sediments. This protocol was also found to be applicable to the isolation of RNA from freshwater planktonic populations and activated sludge (data not shown). Agarose gel electrophoresis of the RNA isolated from sediments demonstrated the presence of intact $23 \mathrm{~S}, 16 \mathrm{~S}$ and $5 \mathrm{~S}$ rRNA molecules (Fig. 1). RNA obtained from $1 \mathrm{~cm}^{3}$ of

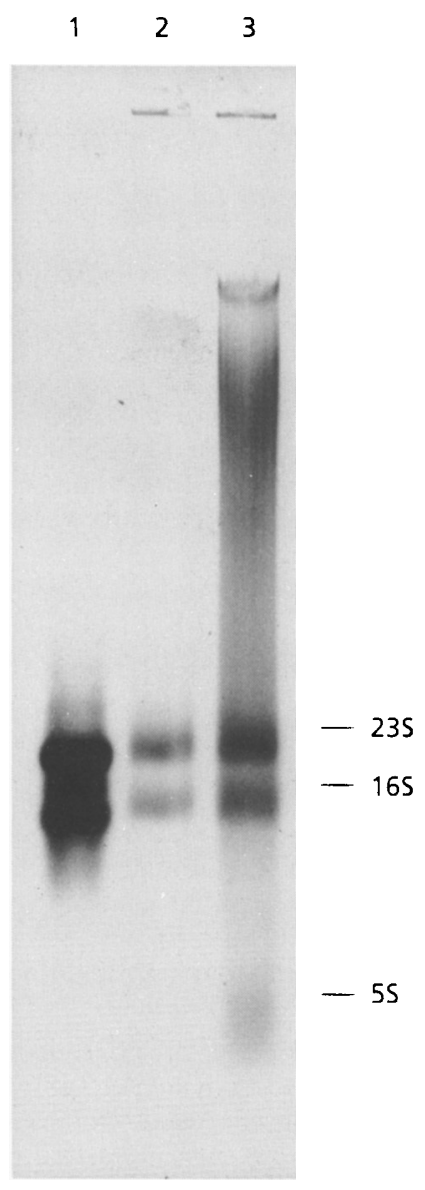

Fig. 1. Nucleic acid extraction from profundal sediments of Priest Pot. Samples loaded are equivalent to $0.5 \mathrm{~cm}^{3}$ of sediment. Lanes: 1, $4 \mu \mathrm{g} \mathrm{E}$. coli $23 \mathrm{~S}$ and 16S rRNA (Boehringer Mannheim); 2 and 3, nucleic acid extract before (3) and after (2) DNase treatment.
$\begin{array}{llllllllllll}M & 1 & 2 & 3 & 4 & 5 & 6 & 7 & 8 & 9 & 10 & M\end{array}$

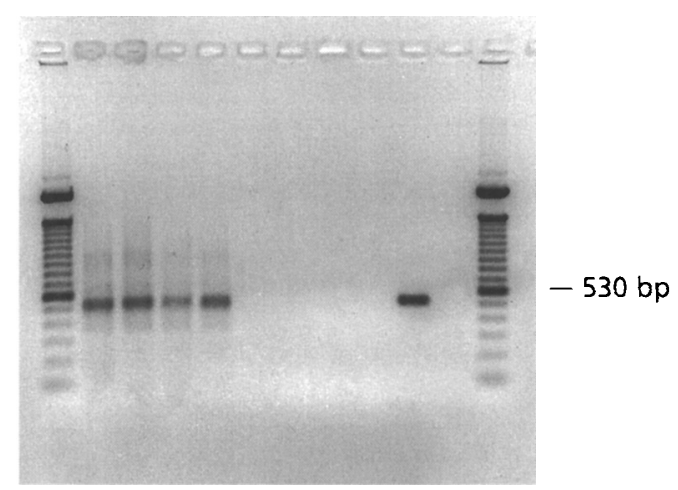

Fig. 2. RT-PCR amplification of $16 \mathrm{~S}$ rRNA from indigenous sediment bacterial communities from Priest Pot. Lanes: 1-4, RTPCR from RNA extracted from sediments at depths of $0,5,10$ and $20 \mathrm{~cm}$, respectively; $5-8$, PCR from the same samples as in lanes $\uparrow-4$ but without reverse transcription of the RNA prior to PCR; 9, PCR positive control (genomic DNA from $E$. coli $A B 1157) ; 10$, distilled water negative control; $M, 100$ bp ladder (Promega).

sediment was of a purity and a quantity suitable for molecular analysis by RT-PCR procedures (Fig. 2).

While the methodology employed is unremarkable, the duration of bead-beating was found to be critical for the preparation of templates amenable to subsequent enzymic treatments. Bead-beating was limited to $20 \mathrm{~s}$, extended periods of agitation resulted in greater coextraction of humic materials without a significant increase in cellular lysis. In addition, it was found that coextraction of enzyme-inhibitory substances was compounded by the inclusion of SDS before bead-beating. Therefore, SDS was added following bead-beating to augment cellular lysis throughout the thermal incubation step. Interestingly, it was observed incidentally that this inhibitory effect was more pronounced in surface rather than subsurface $(>10 \mathrm{~cm}$ depth) sediment samples. It is apparent that even within a single core, variation in sediment characteristics can greatly affect the performance of a nucleic acid extraction technique.

Previously published protocols for the extraction of RTamenable RNA from sediments, although effective, require time-consuming exhaustive dialysis for the removal of humic acids (e.g. Ogram et al., 1995). In contrast, the method presented here permits rapid ( $1 \mathrm{~d})$ RNA extraction from discrete $\left(<1 \mathrm{~cm}^{3}\right)$ sediment samples. The removal of contaminating humic acids was effected rapidly by precipitation with potassium acetate (Smalla et al., 1993). Samples retain a slight yellow colour that is indicative of residual humic acids; however, when diluted, these did not inhibit subsequent enzymic processes.

The suitability of the sediment-extracted RNA for molecular analysis was demonstrated by RT-PCR amplification of both rRNA and mRNA targets. The extraction and amplification of rRNA was relatively 


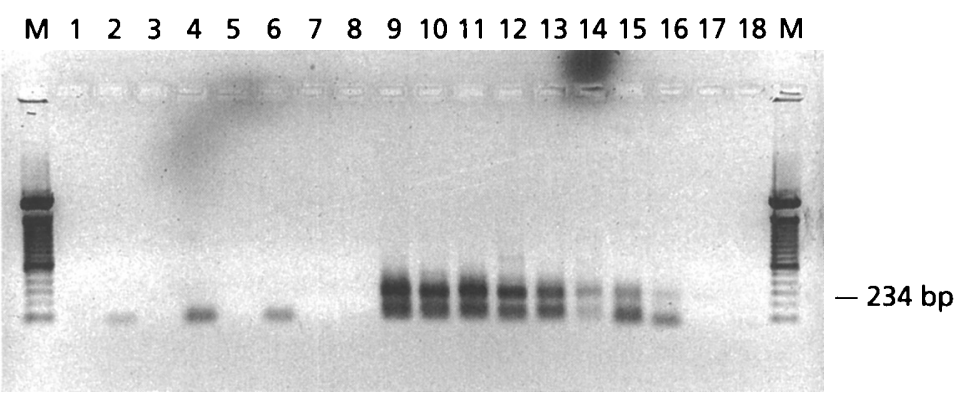

Fig. 3. RT-PCR of merR mRNA extracted from Priest Pot sediment samples. Lanes: 1-8, control PCR amplification with no reverse transcription step; 9-16, pairwise dilutions of merR CDNA reverse transcribed from RNA extracted from sediments at depths of $0,5,10$ and $20 \mathrm{~cm}$, respectively; 17, PCR positive control [DNA from E. coli AB1157(pACYC184::Tn501)]; 18, distilled water negative control; $M, 100$ bp ladder (Promega).

easy to achieve (Fig. 2). This might be expected in a sediment from a highly productive lake with organically rich sediments (total organic carbon, TOC, $15-20 \%$ by weight). More surprising was the successful amplification of mRNA which is typically highly labile and transient (Darnell et al., 1986). The regulatory gene for mercuric reductase was chosen to demonstrate the efficacy of mRNA extraction and it was known that merR genes could be detected in waters and sediments of Windermere and Esthwaite Water nearby (Miskin, 1996). RT-PCR amplification of a $234 \mathrm{bp}$ fragment of merR mRNA from mercury resistance determinants of Gram-negative bacteria was achieved in all Priest Pot sediment-extracted RNA samples to a depth of $20 \mathrm{~cm}$ (Fig. 3). The short half-life of mRNAs implies that merR regulatory genes, or their homologues, were being transcribed in situ. Clearly, without proper quantification no firm conclusions may be drawn regarding levels of gene expression by RT-PCR. Nevertheless, with appropriate methodology, correlation of specific gene expression to activity in sediment samples may be possible using competitive RT-PCR (Lee et al., 1996; Meckenstock et al., 1998).

Partial $16 \mathrm{~S}$ rRNA sequences amplified by RT-PCR from nucleic acids extracted from sediment samples were cloned and sequenced. RT-PCR amplification of near complete 16S rRNA sequences from our RNA extracts was problematic, but it was possible to reproducibly amplify smaller fragments of about $530 \mathrm{bp}$. Consequently, DNA templates were amplified using the same primers used for RT-PCR to ensure that all samples were treated as consistently as possible. As a working hypothesis it was considered that clone libraries derived from RNA and DNA templates were representative of active and 'total' bacterial populations, respectively. However, sequences derived from RT-PCR are not necessarily representative of bacteria with high activity in situ and in studies of cultivated organisms, slow growing or senescent bacteria have been shown to possess significant levels of rRNA (Kramer \& Singleton, 1992, 1993; Binder \& Liu, 1998). It is clearly likely that bacterial cells that were active in the water column will be deposited in sediments. Whether or not such organ- isms are genuinely active in the sediment, they may still retain appreciable levels of RNA and be inferred to be active components of the microbiota. Nonetheless, the presence of rRNA does indicate that the cells were active at some time close to sampling. Furthermore, in Priest Pot the sedimentation rate is 0.5 to $1.0 \mathrm{~cm}$ per year (Cranwell \& Koul, 1989) and we have recovered rRNAderived sequences from depths of up to $20 \mathrm{~cm}$ in the sediment (Fig. 2). Thus any cells from the water column present at this depth will have been buried for 20-40 years and it is unlikely that senescent cells would have retained their rRNA intact for such periods of time unless they were genuinely active in situ.

In total $14716 \mathrm{~S}$ rRNA sequences were obtained from six sedimentary horizons. From RNA and DNA templates, 71 and 76 sequences were derived, respectively. This clone library was diverse and few identical sequences were obtained. An estimation of the efficiency of sampling of natural communities characterized by small subunit (SSU) rRNA gene cloning techniques was presented by Giovannoni et al. (1995):

$C=\left[1-\left(n_{1} / N\right)\right] \times 100$

where $C$ is the percentage coverage of the diversity present in an environmental community obtained in a clone library, $n_{1}$ is the number of clone types occurring only once in the library and $N$ is the total number of clones examined.

If a conservative approach is adopted for this analysis (i.e. sequences with greater than $97 \%$ identity treated as identical; Giovannoni et al., 1995) of Priest Pot clone libraries, coverage values of about 26 and $5 \%$ are obtained for the RNA- and DNA-derived libraries, respectively. If coverage is calculated on the basis of the occurrence of truly unique sequences these values drop to 6 and $4 \%$. Thus the bacterial diversity of Priest Pot sediments was poorly sampled in our clone libraries and one cannot validly conclude that the rRNA- and rDNAderived libraries obtained are truly representative of the active and 'total' bacterial populations. Clearly, to test our original hypothesis rigorously, one would require clone libraries with a higher degree of coverage. How- 
(a)

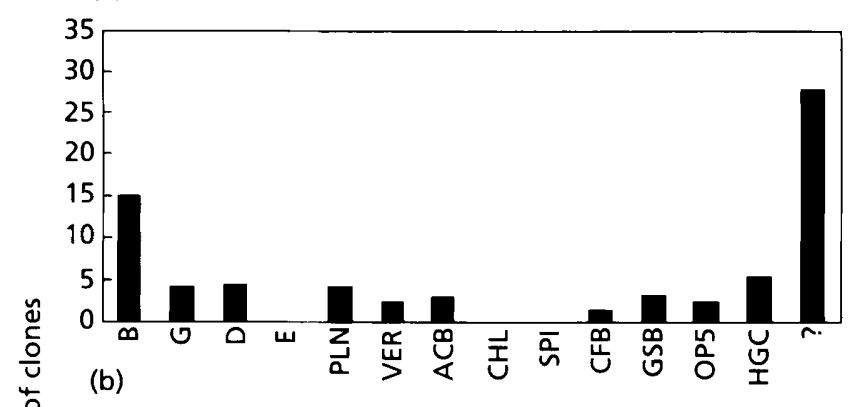

i

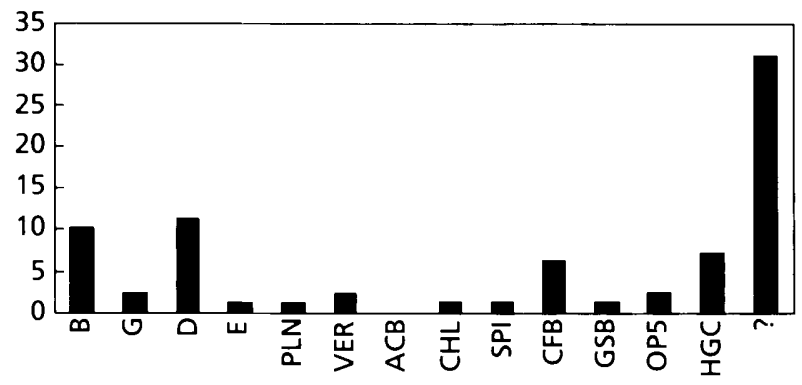

Bacterial division

Fig. 4. Phylogenetic distribution of SSU rRNA sequences recovered from rRNA (a) and rDNA (b) templates extracted from Priest Pot sediments. B, $\beta$-Subclass of the Proteobacteria; $\mathrm{G}, \gamma$-subclass; D, $\delta$-subclass; E, $\varepsilon$-subclass; PLN, Planctomycetales; VER, Verrucomicrobia; $A C B$, Acidobacterium division; $\mathrm{CHL}$, chloroplasts and cyanobacteria; SPI, spirochaetes; CFB, CytophagalFlexibacter/Bacteroides; GSB, green sulfur bacteria; OP5, candidate division OP5; HGC, high $\mathrm{G}+\mathrm{C}$ content Grampositive bacteria; ?, sequences of uncertain phylogenetic affiliation.

ever, the sequences recovered in rRNA-derived clone libraries are likely to represent organisms that are active in situ. Poor sampling of species diversity in bacterial populations using molecular methods is not unprecedented. For example, Borneman et al. (1996) found $4 \%$ coverage among rDNA clones from an agricultural soil in Wisconsin and a study of the microbial diversity in Amazonian soils similarly found that, of 100 isolated sequences, none were duplicated (Borneman \& Triplett, 1997).

\section{Novel taxa in Priest Pot sediments}

It is commonly reported that SSU rRNA sequences recovered from environmental samples have low homology to known bacterial isolates (e.g. Giovannoni et al., 1996). Independent studies of diverse environments increasingly result in the recovery of similar 'novel' sequence types. This suggests that many of the novel sequence types represent bacterial taxa that have ecological significance in a wide range of environments (Hugenholtz et al., 1998b). In this study of Priest Pot bacterial communities, a large proportion of the SSU rRNA sequences obtained exhibited low $S_{\mathrm{AB}}$ values with known reference strains in SIMILARITY-RANK searches of the RDP database (Maidak et al., 1997) and typically had less than $80 \%$ sequence identity with their closest neighbour in FASTA searches of other sequence databases. These sequences could not clearly be associated with any of the divisions currently recognized in the bacterial domain (Fig. 4). This is in part due to the difficulties associated with phylogenetic placement of deeply divergent sequences based on partial sequence data. Practical constraints of our RT-PCR technique restricted us to amplification and analysis of short fragments of SSU rRNA sequence. Although phylogenetic analyses confirmed that a number of the cloned sequences, within the collection from Priest Pot sediments, represented novel phylogenetic lineages and had no known close relatives, in some cases the higher sequence identity to nearest known neighbours (about $90 \%$ ) was noted and the same relationships were recovered using more than one phylogenetic inference technique. Furthermore, other features such as the presence of particular signature nucleotides provided further evidence of their association with particular phylogenetic groups.

Sequences belonging to many of the novel lineages were independently recovered from separate samples and from both rRNA and rDNA templates. The recovery of sequences belonging to novel lineages from rRNA templates also suggests that they derive from cells that were likely to have been active in situ. These key points are clearly demonstrated if we consider sequences related to the Planctomycetales and Verrucomicrobia and the recently described candidate division OP5 obtained in this study.

\section{Priest Pot clones related to the Planctomycetales and Verrucomicrobia}

The Planctomycetales and Verrucomicrobia have been grouped phylogenetically and are now known to be distributed in a much wider range of habitats than was originally perceived (Nold \& Zwart, 1998). Sequences related to these bacteria are routinely noted in $16 \mathrm{~S}$ rDNA clone libraries from environmental samples (Nold \& Zwart, 1998). The isolation of planctomycetelike sequences in this study is in accord with the observation that planctomycetes can be cultured from a broad range of aquatic environments (Staley et al., 1992; Schlesner, 1994) and around $6 \%$ of the sequences recovered from Priest Pot sediments were related to the Planctomycetales and Verrucomicrobia.

Members of the Planctomycetales that have been isolated to date are typically aerobic planktonic bacteria. Since the majority of cultured planctomycetes and their relatives are aerobic and planktonic, it would be expected that SSU rRNA sequences from such bacteria would be obtained from water column samples. However, culture-independent molecular methods reliant on the isolation and sequencing of $16 \mathrm{~S}$ rRNA genes have also indicated that the Planctomycetales may be members of bacterial populations in marine sediments (Gray \& Herwig, 1996) and marine aggregates (DeLong et al., 1993), where low oxygen tensions occur. However, 
Novel bacterial lineages active in freshwater sediments

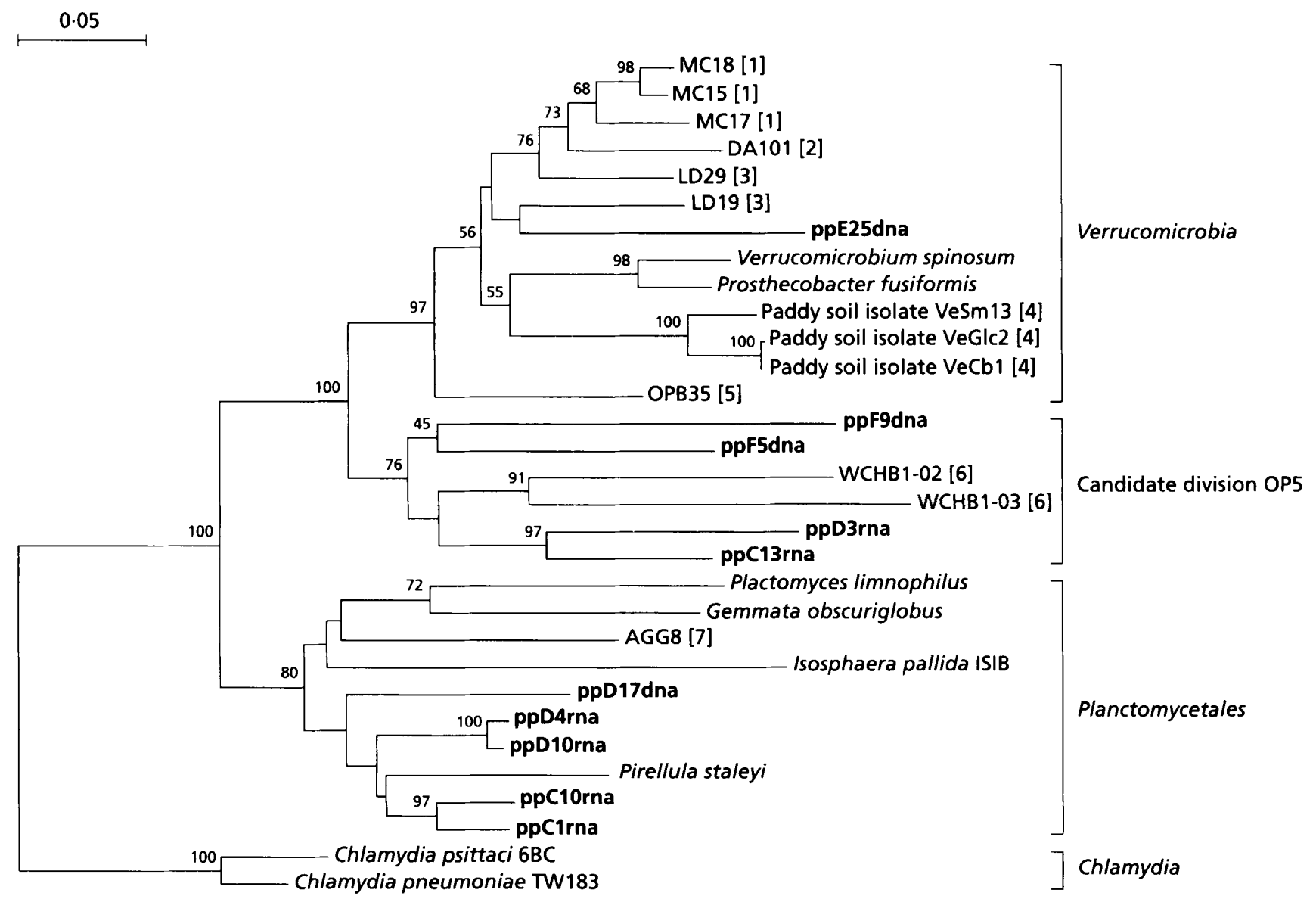

Fig. 5. Neighbour-joining phylogenetic tree showing the evolutionary relationships among SSU rRNA sequences recovered from Priest Pot sediments and previously described sequences belonging to the Planctomycetales and Verrucomicrobia. Cloned sequences from this study are shown in bold and are suffixed with dna or rna, indicating their source template. Numbers in brackets indicate the source of reference sequences: 1, Australian soils (Liesack \& Stackebrandt, 1992); 2, agricultural soil (Felske et al., 1998); 3, freshwater lake (Zwart et al., 1998); 4, paddy soil isolates (Janssen et al., 1997); 5, hot spring (Hugenholtz et al., 1998a); 6, contaminated aquifer (Dojka et al., 1998); 7, marine snow aggregate (DeLong et al., 1993). The tree was constructed using 367 unambiguously aligned bases corresponding to $E$. coli positions 34-68, 101-197 and 218-452 (Brosius et al., 1978). Bootstrap values represent the number of times a group to the right of the node was obtained in trees generated from 100 resampled datasets (values $>40 \%$ are shown). Bar denotes $0.05 \%$ sequence divergence. None of the OP5 sequences originally reported (Hugenholtz et al., 1998a) were included in this analysis since the clone libraries from which these sequences were obtained, were generated from PCR products that covered positions 533-1510 of the 16S rRNA gene (Hugenholtz et al., 1998a).

in view of the exclusively aerobic metabolism of closely related cultured organisms, the activity of planctomycetes identified in anoxic environments from the amplification of $16 \mathrm{~S}$ rDNA can be questioned.

We have made the remarkable observation that sequences most closely related to the planktonic, aerobic heterotroph Pirellula staleyi have been recovered from anoxic sediments of Priest Pot (Fig. 5). The phylogenetic delineation of these Pirellula-like sequences is further supported if we consider the sequences in more detail. The Planctomycetales are known to lack the target site for the Bacteria-specific probe Eub338 (Zarda et al., 1997). The planctomycete-like sequences recovered in this study conform with this observation and the Eub338 target site in these sequences contains three mismatches to the probe sequence. Furthermore, analysis of the signature nucleotides identified by Liesack \& Stackebrandt (1992) as unique to the Planctomycetales and the group now know as the Verrucomicrobia corroborates the phylogenetic assignment of these Priest Pot clone sequences to the Planctomycetales (Table 1).

A number of our Pirellula-like sequences (ppC1rna, ppC10rna, ppD4rna, ppD10rna) were derived by reverse transcription of $\mathrm{rRNA}$, providing evidence that these organisms were metabolically active within the anoxic sediments. Interestingly, Pirellula-like sequences have been recovered from DNA extracted from marine sediments in Puget Sound (Gray \& Herwig, 1996) and marine snow (DeLong et al., 1993). Unfortunately, we could not determine the relationship of these marine sequences to clones from Priest Pot, as the region of the 16S rRNA gene sequenced by these researchers did not 
Table 1. Signature nucleotides of the Planctomycetales and Verrucomicrobia-like clones from Priest Pot

\begin{tabular}{|c|c|c|c|c|c|c|c|c|c|c|c|c|c|}
\hline \multirow[t]{2}{*}{ Position* } & \multicolumn{13}{|c|}{ Nucleotide(s) $\dagger$} \\
\hline & Planciom ycerales $\ddagger$ & ppD4rna & ppD17dna & ppC10rna & ppClrna & ppD10rna & MC Cluster III & V. spinosum & ppA3rna & ppD17rna & ppE25dna & ppF18dna & $\begin{array}{c}\text { Chlamydia } \\
\text { psittaci }\end{array}$ \\
\hline $47 / 394$ & $C_{i-C}$ & $C-G$ & $G_{i}-C_{i}$ & Gi-Gi & G.G & $\mathrm{C} \cdot \mathrm{G}_{\mathrm{I}}$ & $\mathrm{G}-\mathrm{G}$ & $G_{1}-C_{i}$ & $\mathrm{G}-\mathrm{X}$ & $G-X$ & $\mathrm{C}-\mathrm{G}$ & $\mathrm{C}-\mathrm{G}$ & G-Ci \\
\hline 48 & $\mathrm{~A}$ & A & $\mathrm{A}$ & $A$ & A & $A$ & $\mathrm{~A}$ & A & A & A & A & $A$ & A \\
\hline 50 & II & U & U & UI & $\mathrm{U}$ & U & A & A & $\mathrm{A}$ & $A$ & A & $\mathrm{A}$ & G \\
\hline $52 / 359$ & $(i-C)$ & (i-C: & Ci-C & $\mathrm{G} \cdot \mathrm{C}$ & $\mathrm{G}-\mathrm{C}$ & $\mathrm{G}-\mathrm{C}$ & $\mathrm{G} \cdot \mathrm{C}$ & G.C: & $(;-X$ & Gi-X & G-C : & $\mathrm{G}-\mathrm{C}$ & G-C: \\
\hline $53 / 358$ & $\mathrm{Gill}$ & $(i-1)$ & $(j-1)$ & (j- -1 & $(i-U$ & $\mathrm{G} \cdot \mathrm{U}$ & $A-(1$ & $A-()$ & $A-X$ & $A-X$ & $\mathrm{~A}-\mathrm{U}$ & $\mathrm{A}-\mathrm{U}$ & $\mathrm{G}-\mathrm{ll}$ \\
\hline 169 & G & U & Gi & U & U & U & U & U & $C$ & C & $\mathrm{C}$ & $\mathrm{C}$ & C \\
\hline $291 / 309$ & $\mathrm{G}-\mathrm{C}:$ & $\mathrm{C}_{\mathrm{i}}-\mathrm{C}$ & $A-1$ & $G-C$ & $\mathrm{G}-\mathrm{C}$ & $\mathrm{G}-\mathrm{C}:$ & U-A & $\mathrm{U}-\mathrm{A}$ & $\mathrm{U} \cdot \mathrm{A}$ & $\mathrm{U}-\mathrm{A}$ & $\mathrm{U}-\mathrm{A}$ & U.A & $C \cdot G$ \\
\hline 331 & !: & II & li & UI & U & li & G & G & G & G & $G_{3}$ & (i & U \\
\hline 35.3 & U & U & II & U & (I) & U & A & $A$ & $A$ & $\mathrm{~A}$ & $\mathrm{~A}$ & $A$ & UI \\
\hline
\end{tabular}

* Numbering based on the E. coli 16S rRNA gene (Brosius et al., 1978).

$\dagger \mathrm{X}$, Sequence data not available.

$\ddagger$ After Liesack \& Stackebrandt (1992).

coincide with our data. From the evidence of these studies we propose that bacteria closely related to Pirellula spp., while previously thought to be principally aerobic, probably include organisms that exhibit anaerobic metabolism and may comprise an important, active component of bacterial populations in some anoxic sediments. However, to validate this conjecture the abundance of the bacteria represented by these sequences in anoxic environments would need to be determined using whole cell in situ hybridization, for example.

Four $16 \mathrm{~S}$ rRNA sequences that were related to the Verrucomicrobia were also recovered from Priest Pot sediments (Table 1 and Fig. 4). Several of the verrucomicrobial sequences recovered were truncated and thus were not included in the phylogenetic tree shown (Fig. 4). Nonetheless, phylogenetic analyses using shorter sequences and signature nucleotide analysis suggested that these sequences were most closely related to members of the Verrucomicrobia (Table 1 and unpublished data). Most cultured Verrucomicrobia are heterotrophic aerobes (Schlesner, 1994; Hedlund et al., 1996, 1997), though novel aerotolerant fermentative organisms related to Verrucomicrobium spinosum have been cultured recently (Janssen et al., 1997). V. spinosum itself can grow fermentatively and was isolated from a eutrophic alkaline lake ( $\mathrm{pH}$ 9.5) in Germany (Schlesner, 1987). It is notable that the Verrucomicrobia are represented by very few cultured representatives (Hugenholtz et al., 1998b) and the diversity of the group is defined principally from $16 \mathrm{~S}$ rRNA sequences recovered from environmental samples (Liesack \& Stackebrandt, 1992; Ward-Rainey et al., 1995; Lee et al., 1996; Hiorns et al., 1997; Wise et al., 1997; Borneman \& Triplett, 1997; Zwart et al., 1998). Again, the portion of sequence analysed in this study was different from regions sequenced in a number of recent molecular studies that have identified verrucomicrobial sequences. Nonetheless, $16 \mathrm{~S}$ rRNA sequences related to this group have been reported from a wide range of environments, including a soybean field (Ueda et al., 1995), forest and grassland soils (Liesack \& Stackebrandt, 1992; Borne- man et al., 1996; Lee et al., 1996; Borneman \& Triplett, 1997; Felske et al., 1998), Adirondack Mountain lakes (Hiorns et al., 1997), oceanic waters (Fuhrman et al., 1993), freshwater sediments (Wise et al., 1997) and marine sediments (Gray \& Herwig, 1996).

The $16 \mathrm{~S}$ rDNA clone, ppE25dna, recovered from Priest Pot provides the first corroboration of a divergent lineage of the Verrucomicrobia defined by a $16 \mathrm{~S}$ rRNA sequence (LD19) obtained by Zwart et al. (1998) from Lake Loosdrecht in the Netherlands. However, ppE25 dna and LD19 sequences are significantly divergent ( $83 \%$ sequence homology) and the relationship is not strongly supported by bootstrap resampling or parsimony analysis. Analysis of signature nucleotide positions supports the position of the ppE25dna sequence within the Verrucomicrobia (Table 1). Thirteen of the signature positions identified as characteristic of Verrucomicrobia (Liesack \& Stackebrandt, 1992) were present in the partial 16S DNA sequence of clone ppE25dna. Of these, 11 were identical with the verrucomicrobial signatures. The nearest phylogenetic neighbours to this poorly defined clade are also cloned $16 \mathrm{~S}$ rDNA gene sequences that were recovered from an Australian forest soil (Liesack \& Stackebrandt, 1992), grassland soil in the Netherlands (Felske et al., 1998) and Lake Loosdrecht in the Netherlands (Zwart et al., 1998).

\section{Support for the candidate division OP5}

Some of the most interesting sequences isolated by RTPCR from the sediments of Priest Pot were originally interpreted as forming a novel deep branching lineage related to the Verrucomicrobia. However, it is now apparent that these sequences belong to a novel lineage described for the first time only recently (Hugenholtz et al., 1998a). The clones-ppF5dna, ppF9dna, ppD3rna and ppC13rna-define a clade with two sequences, WCHB1-02 and WCHB1-03, recovered from community DNA extracted from a contaminated aquifer (Dojka et al., 1998). The integrity of these sequences is supported not only by correlation with the WCHB clones but also since these four sequences were isolated 
from three independently obtained samples. Furthermore, two were derived from rDNA and two from rRNA templates. These sequences group together $(76 \%$ bootstrap support) forming a deep-rooting lineage which has been proposed to represent a novel division (OP5) in the bacterial domain (Hugenholtz et al., $1998 \mathrm{a}, \mathrm{b})$. This relationship was also recovered in parsimony analysis. It is probable that the clustering of candidate division OP5 close to the root of the Verrucomicrobia is artifactual since all OP5 clones have sequences complementary to the Eub338 hybridization probe and lack the Planctomycetales and verrucomicrobial signature nucleotides. The strong bootstrap support for this relationship is a consequence of the selection of sequences used in the analysis. In analyses using other reference sequences the OP5 group remained coherent but its relationship to other taxa was unclear.

Sequences belonging to the candidate division OP5 have also been obtained from hydrocarbon-contaminated soil under methanogenic conditions (Dojka et al., 1998) and from sediment from a hot spring (Hugenholtz et al., 1998a). The hot spring sediment is also likely to have been anoxic since it was reported that it contained high levels of reduced iron (Hugenholtz et al., 1998a). It is thus interesting to note that, to date, all sequences belonging to the OP5 division have come from anoxic environments, suggesting that members of OP5 may be anaerobes. The recovery of sequences affiliated with the candidate division OP5 from Priest Pot sediments reaffirms the assumption that this novel bacterial taxon is widely distributed (Hugenholtz et al., 1998b) and inhabits diverse environments (Hugenholz et al., 1998a ; Dojka et al., 1998). Furthermore, the identification of two of these sequence types, ppD3rna and ppC13rna, in libraries derived from an RNA template from Priest Pot sediments provides the first evidence for in situ metabolic activity of bacteria from the candidate division OP5. Nonetheless, full evaluation of the importance of these bacteria in anoxic environments will require their abundance to be determined using, for example, whole cell in situ hybridization techniques or quantitative slotblot hybridization of RNA extracted from environmental samples. Ultimately, determination of the function of such uncultured bacterial taxa will require their isolation in axenic culture.

\section{ACKNOWLEDGEMENTS}

This work was funded by NERC grant GST/02/1018 awarded to I. M.H and P.F. The authors are grateful to Dr R. Pickup of the Institute for Freshwater Ecology and Paul Fox for assistance with sampling. Dr K. Bruce of the University of Liverpool is thanked for providing the $m e r R$ primers.

\section{REFERENCES}

Binder, B. J. \& Liu, Y. C. (1998). Growth rate regulation of rRNA content of a marine Synechococcus (Cyanobacterium) strain. Appl Environ Microbiol 64, 3346-3351.

Blumberg, D. D. (1987). Creating a ribonuclease-free environment. Methods Enzymol 152, 20-24.
Borneman, J. \& Triplett, E. W. (1997). Molecular microbial diversity in soils from Eastern Amazonia: Evidence for unusual microorganism and microbial population shifts associated with deforestation. Appl Environ Microbiol 53, 2647-2653.

Borneman, J., Skroch, P. W., O'Sullivan, K. M., Palus, J. A., Rumjanek, N. G., Jansen, J. L., Nienhuis, J. \& Triplett, E. W. (1996). Molecular microbial diversity of an agricultural soil in Wisconsin. Appl Environ Microbiol 62, 1935-1943.

Brosius, J., Palmer, J. L., Kennedy, J. P. \& Noller, H. F. (1978). Complete nucleotide sequence of a $16 \mathrm{~S}$ ribosomal gene from Escherichia coli. Proc Natl Acad Sci USA 75, 4801-4805.

Brown, N. L., Ford, S. J., Pridmore, R. D. \& Fritzinger, D. C. (1983). Nucleotide sequence of a gene from the Pseudomonas transposon Tn501 encoding mercuric reductase. Biochemistry 22, 4089-4095.

Coolen, M. J. L. \& Overmann, J. (1998). Analysis of subfossil molecular remains of purple sulfur bacteria in a lake sediment. Appl Environ Microbiol 64, 4513-4521.

Cranwell, P. A. \& Koul, V. K. (1998). Sedimentary record of polycyclic aromatic hydrocarbons in the Windermere catchment. Water Res 23, 275-283.

Darnell, J., Lodish, H. \& Baltimore, D. (1986). RNA synthesis and processing in Eukaryotes. In Molecular Cell Biology, pp. 305-369. Scientific American Books.

DeLong, E. F., Franks, D. G. \& Yayanos, A. A. (1993). Phylogenetic diversity of aggregate-attached vs. free-living marine bacterial assemblages. Limnol Oceanogr 38, 924-934.

Dojka, M. A., Hugenholtz, P., Haack, S. K. \& Pace, N. R. (1998). Microbial diversity in a hydrocarbon- and chlorinated-solventcontaminated aquifer undergoing intrinsic bioremediation. Appl Environ Microbiol 64, 3869-3877.

Edwards, U., Rogall, T., Blöcker, H., Emde, M. \& Bottger, E. C. (1988). Isolation and complete nucleotide determination of entire genes. Characterisation of a gene coding for $16 \mathrm{~S}$ ribosomal RNA. Nucleic Acids Res 17, 7843-7853.

Felsenstein, J. (1989). PHYLIP-phylogeny inference package. Cladistics 5, 164-166.

Felske, A., Engelen, B., Nübel, U. \& Backhaus, H. (1996). Direct ribosome isolation from soil to extract bacterial rRNA for community analysis. Appl Environ Microbiol 62, 4162-4167.

Felske, A., Wolterink, A., van Lis, R. \& Akkermans, A. D. L. (1998). Phylogeny of the main bacterial 16S rRNA sequences in Drentse A grassland soils (The Netherlands). Appl Environ Microbiol 64, 871-879.

Fleming, J. T., Sanseverino, J. \& Sayler, G. S. (1993). Quantitative relationship between napthalene catabolic gene frequency and expression in predicting PAH degradation in soils at town gas manufacturing sites. Environ Sci Technol 27, 1068-1074.

Fuhrman, J. A., McCallum, K. \& Davis, A. A. (1993). Phylogenetic diversity of subsurface marine microbial communities from the Atlantic and Pacific Oceans. Appl Environ Microbiol 59, 1294-1302.

Fuhrman, J. A., Lee, S. H., Masuchi, Y., Davis, A. A. \& Wilcox, R. M. (1994). Characterisation of marine prokaryotic communities via DNA and RNA. Microb Ecol 28, 133-145.

Giovannoni, S. J., Britschgi, T. B., Moyer, C. L. \& Field, K. G. (1990). Genetic diversity in Sargasso Sea bacterioplankton. Nature 345, 60-63.

Giovannoni, S. J., Mullins, T. D. \& Field, K. G. (1995). Microbial diversity in oceanic systems: rRNA approaches to the study of unculturable microbes. In Molecular Ecology of Aquatic Microbes. NATO ASI Series, Series G, Ecological Sciences, No. 38, pp. 217-248. Edited by I. Joint. Berlin: Springer. 
Giovannoni, S. J., Rappé, M. S., Gordon, D., Urbach, E., Suzuki, M. \& Field, F. G. (1996). Ribosomal RNA and the evolution of bacterial diversity. In Evolution of Microbial Life. Society for General Microbiology Symposium, vol. 54. Edited by D. McL. Roberts, P. Sharp, G. Alderson \& M. Collins. Cambridge: Cambridge University Press.

Gordon, D. A. \& Giovannoni, S. J. (1996). Detection of stratified microbial populations related to Chlorobium and Fibrobacter species in the Atlantic and Pacific Oceans. Appl Environ Microbiol 62, 1171-1177.

Gray, J. P. \& Herwig, R. P. (1996). Phylogenetic analysis of the bacterial communities in marine sediments. Appl Environ Microbiol 62, 4049-4059.

Hedlund, B. P., Gosink, J. J. \& Staley, J. T. (1996). Phylogeny of Prosthecobacter, the fusiform Caulobacters: Members of a recently discovered division of the Bacteria. Int J Syst Bacteriol 46, 960-966.

Hedlund, B. P., Gosink, J. J. \& Staley, J. T. (1997). Verrucomicrobia div. nov., a new division of the Bacteria containing three new species of Prosthecobacter. Antonie Leeuwenhoek 72, 29-38.

Herrick, J. B., Madsen, E. L., Batt, C. L. \& Ghiorse, W. C. (1993). Polymerase chain reaction amplification of napthalene-catabolic and $16 \mathrm{~S}$ ribosomal-RNA gene-sequences from indigenous sediment bacteria. Appl Environ Microbiol 59, 687-694.

Hiorns, W. D., Methé, B. A., Nierzwicki-Bauer, A. \& Zehr, J. P. (1997). Bacterial diversity in Adirondack Mountain lakes as revealed by $16 \mathrm{~S}$ rRNA gene sequences. Appl Environ Microbiol 63, 2957-2960.

Höle, M. G. (1992). Bacterioplankton community structure and dynamics after large-scale release of nonindigenous bacteria as revealed by low-molecular-weight-RNA analysis. Appl Environ Microbiol 58, 3387-3394.

Hugenholtz, P., Pitulle, C., Hershberger, K. L. \& Pace, N.R. (1998a). Novel division level bacterial diversity in a Yellowstone hot spring. J Bacteriol 180, 366-376.

Hugenholtz, P., Goebel, B. M. \& Pace, N. R. (1998b). Impact of culture-independent studies on the emerging phylogenetic view of bacterial diversity. J Bacteriol 180, 4765-4774.

Janssen, P. H., Schuhmann, A., Morschel, E. \& Rainey, F. A. (1997). Novel anaerobic ultramicrobacterium belonging to the Verrucomicrobiales lineage of bacterial descent isolated by dilution culture from anoxic rice paddy soil. Appl Environ Microbiol 63, $1382-1388$.

Jeffrey, W. H., Nazaret, S. \& von Haven, R. (1994). Improved method for recovery of mRNA from aquatic samples and its application to detection of mer expression. Appl Environ Microbiol 60, 1814-1821.

Jukes, T. H. \& Cantor, C. R. (1969). Evolution of protein molecules. In Mammalian Protein Metabolism, vol. 3, pp. 21-132. Edited by H. N. Munro. New York: Academic Press.

Kramer, J. G. \& Singleton, F. L. (1992). Variations in rRNA content of marine Vibrio spp. during starvation-survival and recovery. Appl Environ Microbiol 58, 201-207.

Kramer, J. G. \& Singleton, F. L. (1993). Measurement of rRNA variations in natural communities of microorganisms on the southeastern US continental shelf. Appl Environ Microbiol 59, 2430-2436.

Lane, D. J., Pace, B., Olsen, G. J., Stahl, D. A., Sogin, M. L. \& Pace, N. R. (1985). Rapid determination of $16 \mathrm{~S}$ ribosomal RNA sequences for phenotypic analysis. Proc Natl Acad Sci USA 82, 6955-6959.

Lee, S. \& Kemp, P. F. (1994). Single-cell RNA content of natural marine planktonic bacteria measured by hybridization with multiple $16 \mathrm{~S}$ rRNA-targetted fluorescent probes. Limnol Oceanogr 39, 869-879.

Lee, S.-Y., Bollinger, J., Bezdicek, D. \& Ogram, A. (1996). Estimation of the abundance of an uncultured soil bacterial strain by a competitive quantitative PCR method. Appl Environ Microbiol 62, 3787-3793.

Liesack, W. \& Stackebrandt, E. (1992). Occurrence of novel groups of the domain Bacteria as revealed by analysis of genetic material isolated from an Australian terrestrial environment. J Bacteriol 174, 5072-5078.

Maidak, B. L., Olsen, G. J., Larsen, N., Overbeek, R., McCaughey, M. J. \& Woese, C. R. (1997). The RDP (Ribosomal Database Project). Nucleic Acids Res 25, 109-111.

Meckenstock, R., Steinle, P., van der Meer, J. R. \& Snozzi, M. (1998). Quantification of bacterial mRNA involved in degradation of 1,2,4-trichlorobenzene by Pseudomonas sp. strain 51 from liquid culture and from river sediment by reverse transcriptase PCR (RT/PCR). FEMS Microbiol Lett 167, 123-129.

Miskin, I. P. (1996). Bacteria and their transmissible elements within the post-glacial sediments of Windermere: a molecular analysis. PhD thesis, University of Liverpool.

Moran, M. A., Torsvik, V. L., Torsvik, T. \& Hodson, R. E. (1993). Direct extraction and purification of rRNA for ecological studies. Appl Environ Microbiol 59, 915-918.

Mullis, K. B. (1991). The polymerase chain reaction in an anemic mode: how to avoid cold oligodeoxyribonuclear fusion. PCR Methods Appl 1, 1-4.

Nazaret, S., Jeffery, W. H., Saouter, E., von Haven, R. \& Barkay, T. (1994). mer $A$ gene expression in aquatic environments measured by mRNA production and $\mathrm{Hg}(\mathrm{II})$ volatization. Appl Environ Microbiol 60, 4059-4065.

Nold, S. C. \& Zwart, G. (1998). Patterns and governing forces in aquatic microbial communities. Aquatic Ecology 32, 17-35.

Ogram, A., Sayler, G. S. \& Barkay, T. (1987). The extraction and purification of microbial DNA from sediments. J Microbiol Methods 7, 57-66.

Ogram, A., Sun, W., Brockman, F. J. \& Fredrickson, J. K. (1995). Isolation and characterisation of RNA from low-biomass deepsubsurface sediments. Appl Environ Microbiol 61, 763-768.

Ohnstad, F. R. \& Jones, J. G. (1982). The Jenkin Surface Mud Sampler: User Manual. Occasional Publication No. 15. Ambleside: Freshwater Biological Association.

Pichard, S. L. \& Paul, J. H. (1991). Detection of gene expression in genetically engineered microorganisms and natural populations in the marine environment by mRNA analysis. Appl Environ Microbiol 57, 1721-1728.

Pichard, S. L. \& Paul, J. H. (1993). Gene expression per gene dose, a specific measure of gene expression in aquatic microorganisms. Appl Environ Microbiol 59, 451-457.

Pitcher, D. G., Saunders, N. A. \& Owen, R. J. (1989). Rapid extraction of bacterial genomic DNA with guanidinium thiocyanate. Lett Appl Bacteriol 8, 151-156.

Purdy, K. J., Embley, T. M., Takii, S. \& Nedwell, D. B. (1996). Rapid extraction of DNA and RNA from sediments with a novel hydroxyapatite spin-column method. Appl Environ Microbiol 62, 3905-3907.

Rosset, R., Julien, J. \& Monier, M. (1966). Ribonucleic acid composition of bacteria as a function of growth rate. $J \mathrm{Mol}$ Biol 18, 308-320.

Saitou, N. \& Nei, M. (1987). The neighbor-joining method: a new 
method for reconstructing phylogenetic trees. Mol Biol Evol 4, 406-425.

Schlesner, H. (1987). Verrucomicrobium spinosum gen. nov., sp. nov. : a fimbriated prosthecate bacterium. Syst Appl Microbiol 10, 54-56.

Schlesner, H. (1994). The development of media suitable for the microorganisms morphologically resembling Planctomyces spp., Pirellula spp., and other Planctomycetales from various aquatic habitats using dilute media. Syst Appl Microbiol 17, 135-145.

Smalla, K., Cresswell, N., Mendoca-Hagler, L. C., Walters, A. \& van Elsas, J. D. (1993). Rapid DNA extraction protocol from soil for polymerase chain reaction-mediated amplification. $J$ Appl Bacteriol 74, 78-85.

Smith, S. W., Overbeek, R., Woese, C. R., Gilbert, W. \& Gillevet, P. M. (1994). The genetic data environment an expandable GUI for multiple sequence analysis. Comput Appl Biosci 10, 671-675.

Staley, J. T., Fuerst, J. A., Giovannoni, S. J. \& Schlesner, H. (1992). The order Planctomycetales and the genera Planctomyces, Pirellula, Gemmata and Isosphaera. In The Prokaryotes, pp. 3701-3731. Edited by A. Balows, H. G. Trüper, M. Dworkin, W. Harder \& K.-H. Schleifer. New York: Springer.

Teske, A., Wawer, C., Muyzer, G. \& Ramsing, N. B. (1996). Distribution of sulfate-reducing bacteria in a stratified fjord (Mariager Fjord, Denmark) as evaluated by most-probablenumber counts and denaturing gradient gel electrophoresis of PCR-amplified ribosomal DNA fragments. Appl Environ Microbiol 62, 1405-1415.

Tsai, Y.-L. \& Olson, B. H. (1992). Rapid method for separation of bacterial DNA from humic substrates in sediments for Polymerase Chain Reaction. Appl Environ Microbiol 58, 2292-2295.

Tsai, Y.-L., Tran, B., Sangermano, L. R. \& Palmer, C. L. (1993). Simple method of concentrating Enteroviruses and Hepatitis A virus from sewage and ocean water for rapid detection by reverse transcriptase-polymerase chain reaction. Appl Environ Microbiol 59, 3488-3491.
Ueda, T., Suga, Y. \& Matsuguchi, T. (1995). Molecular phylogenetic analysis of a soil microbial community in a soyabean field. Eur J Soil Sci 46, 415-421.

Van de Peer, Y. \& de Wachter, R. (1994). Treecon for windows a software package for the construction and drawing of evolutionary trees for the Microsoft Windows environment. Comput Appl Biosci 10, 569-570.

Ward, D. M., Bateson, M. M., Weller, R. \& Ruff-Roberts, A. L. (1992). Ribosomal RNA analysis of microorganisms as they occur in nature. Adv Microb Ecol 12, 219-286.

Ward-Rainey, N., Rainey, F. A., Schlesner, H. \& Stackebrandt, E. (1995). Assignment of hitherto unidentified 16S rDNA species to a main line of descent within the domain Bacteria. Microbiology 141, 3247-3250.

Weller, R. \& Ward, D. M. (1989). Selective recovery of $16 \mathrm{~S}$ rRNA sequences from natural microbial communities in the form of cDNA. Appl Environ Microbiol 55, 1818-1822.

Wise, M. G., McArthur, J. V. \& Shimkets, L. J. (1997). Bacterial diversity of a Carolina Bay as determined by $16 \mathrm{~S}$ rRNA gene analysis: confirmation of novel taxa. Appl Environ Microbiol 63, 1505-1514.

Zarda, B., Hahn, D., Chatzinotas, A., Schönhuber, W., Neef, A., Amann, R. I. \& Zeyer, J. (1997). Analysis of bacterial community structure in bulk soil by in situ hybridisation. Arch Microbiol 168, 185-192.

Zwart, G., Huismans, R., Van Agterveld, M. P., Van de Peer, Y., De Rijk, P., Eenhoorn, H., Muyzer, G., Van Hannen, E. J., Gons, H. J. \& Laanbroek, H. J. (1998). Divergent members of the bacterial division Verrucomicrobiales in a temperate freshwater lake. FEMS Microbiol Ecol 25, 159-169.

Received 10 December 1998; revised 31 March 1999; accepted 30 April 1999. 